\title{
The Comparison on Evaluation of Concept Map and Structured Grid with Multiple-Choice Test
}

\author{
Buğrahan EKİN*, Şafak ULUÇINAR SAĞIR and Fatih SALTAN \\ Amasya University, Amasya, Turkey
}

\begin{abstract}
The desire to measure students' affective and psychomotor skills along with cognitive abilities created a necessity to switch to new approaches in assessment and evaluation methods. The aim of the study is to compare the concept map and structured grid with the achievement test. The research questions are; 1) Is there a significant correlation between students' concept map points, structured grid points and achievement test points?, 2) How is changing the students' achievement test points, concept map activity points and structured grid points? and 3) Is there a significant difference between students' concept map activity points and students' structured grid activity points based on gender? The relational screening method, which is a quantitative research design is used in this study for research method. The sample of this study includes 23 sixth grade students who are being educated at Atatürk Middle School in Vezirköprü town at 20142015 academic year. In this study, two concept map activities and a structured grid made by researchers were applied with an achievement test which was multiple-choice test prepared by Ceylan (2008) to the students at the end of the unit. Spearman-rho test done by researchers to see the correlation between the points obtained from concept map activities, structured grid and achievement test. A high, significantly positive relationship was found between achievement test points and concept map filling activity points. A significant positive relationship was found between the achievement test and concept map creating activity points. It is can be said that, concept map activities served their purpose and they could measure the same skills with achievement test. However, there weren't any significant relationship found between structured grid and achievement test points. It was thought that, this result occurred because of students weren't accustomed to structured grids. There weren't any significant relationship found between the points obtained from concept map activities and structured grid points. Descriptive analysis was performed to find answers to the second research question. It was seen in the results of the analysis that, students' highest arithmetic mean came from achievement test. It was thought that, these results occurred because of students familiarity with multiple-choice tests. The arithmetic mean of students' concept map filling activity points were found higher than the arithmetic mean of students' concept map creating activity points. This result can be read as, students couldn't create the links between concepts. Mann Whitney U test was performed to find
\end{abstract}

\footnotetext{
* Buğrahan EKİN, Primary School Science Education Master Student, Amasya University, Amasya, Turkey, e-mail:
} 
answers to last research question. It was seen in the test results that, there weren't any effects to these activities points' by gender. Teachers can be informed about alternative assessment and evaluation tools. Alternative assessment and evaluation methods can be use in addition to traditional methods for evaluation.

Keywords: Concept map; structured grid; alternative assessment and evaluation methods; electricity in our lives

\section{Introduction}

Measuring in education is defined as, "to determine student's knowledge, skills and behaviors in short his capacity at the academic level" (Ogan Bekiroğlu, 2004, p.3). We can use assessment and evaluation methods to determine the deficiencies, which are occurring in the teaching process, or to determine the qualifications that can occur at the end of the process (Tan, 2008).

Learning does not occur only in the cognitive field. Not only cognitive characteristics but also affective and psychomotor skills should be measured. Because the traditional measuring methods only focused on cognitive achievement, new approaches and methods were needed in the assessment and evaluation area, and it was started with changing teaching programs. The requirement of the use of alternative assessment tools is available in the curriculum but it appears, this is not fully implemented (Adanalı \& Doğanay, 2010; Akbaş \& Gençtürk, 2013).

There is much information in the literature about alternative assessment methods' benefits to education process (Duban \& Küçükyılmaz, 2008; Şaşmaz Ören, Ormancı \& Evrekli, 2011; Y1ldız \& Uyanık, 2004). Examples of such benefits can be given like; to facilitate the keeping of the details in the students' mind, to provide to evaluate students in many ways and to increase students' attitudes to the course with positively (Batd1, 2014; Gedizgil \& Deryakulu, 2008; Y1ld1z \& Uyanık, 2004). Alternative assessment and evaluation techniques can increase the students' participation in the lesson and can give the students opportunities for expressing themselves by using a student-centered approach (Y1ld1z \& Uyanık, 2004). Gedizgil and Deryakulu (2008) reported that using the concept maps created a positive impact to students' attitudes for computers. Şaşmaz Ören et all. (2011) mentioned that, when prospective science teachers assigned, they want to use alternative assessment techniques and they think these methods will improve effective and permanent learning. Alternative assessment and evaluation methods allow educators to be more objective in students evaluation process, and provides an opportunity for evaluating students through different angles (Duban \& Küçükyılmaz, 2008). Furthermore, these methods can reveal individual differences of the students and this situation can develop their creativity (Duban \& Küçükyılmaz, 2008). Öztürk, Yalvaç Hastürk and Demir (2013) said that, the using of alternative assessment methods in the class, can provide students' participation in an active way with having fun, can have a positive effect on students' self-confidence, can refer students to do research, and can allow students to do self and peer assessments. It is known that, teachers have positive opinions about alternative assessment and evaluation techniques (Akbaş \& Gençtürk, 2013; Duban \& Küçükyılmaz, 2008; Kuran \& Kanatl1, 2009). In the literature it is known that, teacher have less service years have more positive opinions than teachers who have more service years (Karamustafaoğlu, Çağlak \& Meşeci, 2012; Kaya, Balay \& Göçen, 2012; Okur \& Azar, 2011). Sağlam-Arslan, Avc1 and İyibil (2008), Şenel Çoruhlu, Er Nas and Çepni (2009) and Güneş, Dilek, Hoplan, Çelikoğlu and Demir (2010) stated that, teachers do not have enough information to use alternative assessment and evaluation methods. There are 
some studies stated that, teachers have positive opinions about alternative assessment and evaluation techniques (Akbaş \& Gençtürk, 2013).

There are some reasons for choosing traditional assessment methods instead of alternative assessment techniques for use by teachers which are; teachers' have lack of information about alternative assessment techniques, the alternative assessment techniques preparation process is time-consuming, and alternative assessment methods put more responsibilities on teachers (Akbaş \& Gençtürk, 2013; Karakuş \& Öztürk Demirbaş, 2011; Kuran \& Kanatl1, 2009; Okur \& Azar, 2011; Özsevgeç \& Karamustafaoğlu, 2010). Apart from that, lack of time, crowded classes, test systems and teachers lack of information about methods may be indicate for reasons of choosing traditional assessment methods (Sağlam-Arslan et all., 2008; Özsevgeç \& Karamustafaoğlu, 2010; Usta, Çı̆̆ır Dikyol \& İnce, 2010; Güneş et all., 2010; Büyüktokatlı \& Bayraktar, 2014).

Concept maps, structured grids, students' portfolios, diagnostic trees, and mind maps can be mentioned for alternative assessment and evaluation tools (Bahar, Nartgün, Durmuş \& Biçak, 2006). Concept map is a teaching strategy that links between individuals learning paths and the things that the students' learned (Kaptan, 1998). Doris emphasized that, it is necessary to examine student activities in many ways to understand students' using and understanding skills of scientific concepts (as cited in Korkmaz \& Kaptan, 2005). Novak and Gowin (1984) mentioned that, concept-mapping methods can be an educational tool which can uncover what students' learned. The literature states that concept maps can used for learning, teaching and as a measurement tool (Çıldır \& Şen, 2006). There are some studies indicating that, concept maps are more commonly used than project and performance evaluation techniques (Akbaş \& Gençtürk, 2013; Çalışkan \& Kaşıkçı, 2010; Kuran \& Kanatlı, 2009; Özdemir, 2010; SağlamArslan et all., 2008). A study conducted by Usta et all. (2010) indicated that, project, concept maps, and students' portfolios are preferred from alternative assessment methods for student evaluation by prospective science teachers. Kaptan (1998) says that, concept maps can be used as assessment tools and it can be helpful for indicating the concepts that students are having difficulties learning. A study conducted by Korkmaz and Kaptan (2002) stated that, concept maps make a positive effect to conceptual development. In the literature there is much information about concept maps used as an assessment tool. Kandil İngeç (2008) and Özdemir (2005) investigated the correlation between achievement test scores and concept maps scores. Altınok and Ün Açıkgöz (2006) stated that, collaborative concept mapping method had a positive effect to students' attitudes for science lesson. In the same study Altınok and Ün Açıkgöz (2006) said that, individual concept mapping method had also increased the attitude points for science lesson but this increment was not important. Güneş et all. (2010) stated that, teachers think about concept maps that, concept maps being helpful to repeat the subjects and establish ties between concepts by students. Besides Batd1 (2014), and Gedizgil and Deryakulu (2008) stated that, concept maps have positive effects when they use in learning environment.

Because of the answers can be given to students in a several boxes, structured grid technic can be seen as an alternative to multiple choice tests (Durmuş \& Karakırık, 2005). Çalışkan and Kaşıkçı (2010) indicated that, diagnostic tree, structured grid, word association test and group and peer assessment forms not to be much chose to use by teachers as an alternative assessment and evaluation methods. Büyüktokatlı and Bayraktar (2014) stated that, peer assessment, structured grid, diagnostic tree and portfolio techniques are the least-used techniques by teachers as alternative assessment techniques. In the literature, teachers' lack of knowledge is given as the reason of less using of structured grid and diagnostic tree 
techniques (Sağlam-Arslan et all., 2008). In a study Yeşilyurt (2012) indicated that, science teachers more used traditional methods than alternative assessment techniques to evaluate the students but nevertheless they slightly used alternative assessment techniques like concept map and structured grid.

\section{Methodology}

\section{The purpose of the study}

The purpose of this study is to investigate the correlation between students' concept map points, students' structured grid points and students' achievement test points. In this study, researchers looked for answers to this questions; "Is there a significant relationship between students' concept map points, students' structured grid points and students' achievement test points?", "How are changing the students' concept map activity points and students' structured grid points?" and "Is there a significant difference between students' concept map activity points and students' structured grid activity points based on gender?".

\section{Model}

This study was performed using relational screening method, which is a quantitative research design. Karasar mentioned that, this method is used to find the presence and degree of multiple variables (as cited in Güleç \& Alkıç, 2003)

\section{Sample}

The population of this study consists of sixth grade students in primary education schools in Vezirköprü, a town in Samsun, Turkey. The sample of this study includes 23 sixth grade students who are learning at Atatürk Middle School in Vezirköprü for the 2014-2015 academic year.

\section{Data collection tools}

In this study researchers used concept map activities, structured grid and a achievement test for data collection. The concept map activities and structured grid are prepared by researchers. The achievement test is prepared by Ceylan (2008). The achievement test is a multiple-choice test, has 25 items and every item has four choices. The achievement test is prepared with taking into consideration the misconceptions of students and achievements of subject. After pilot implementations, the items which are reduce the reliability was removed from test and the test has taken its final shape. The test's reliability coefficient is $\alpha=0.60$. In the same study mentioned that, this value is on the limits and therefore they take an expert opinion before using the test. It is stated that, with expert opinions, it was decided that the test is applicable and reliable.

In this study, researchers prepared a structured grid and therefore contact an expert for taking feedback for it. Researchers take expert opinions for content validity of structured grids. The structured grid fixed according to the feedbacks and used in the study. The structured grid scored for the reliability by two raters who were unaware of each other. After that, the scores were compared. Five papers selected randomly and used for rater consistency. It is seen that, the raters give the same score to two papers (\%100), the rater consistency on the others 
calculated are $0.97 ; 0.96 ; 0.91$. Therefore overall of rater consistency was found 0.96 , which means it is reliable.

In this study, researchers conducted two concept map activities. In one of the activity, researchers asked students to fill in the blanks on the concept map that are prepared by researchers. On the other concept map activity, researchers gave some concepts and asked to students to create a concept map. Researchers contact an expert for taking feedback about concept map activities' validity. To ensure content validity of concept map activities, researchers take opinions from experts. Two raters, who were unaware with each other, scored the concept maps for the reliability. After that, the scores were compared. Five papers selected randomly from filling concept map activity papers and used for rater consistency. It is seen that, the raters give the same score to two papers (\%100), the rater consistency on the others calculated are $0.72 ; 0.88 ; 0.87$. Therefore overall of rater consistency was found 0.89 . The same process was done with creating concept map activity papers. Five papers selected randomly from creating concept map activity papers and used for rater consistency. The results showed that, the raters give the same score to one paper (\%100), the rater consistency on the others calculated are $0.80 ; 0.77 ; 0.86 ; 0.75$. Therefore overall of rater consistency was found 0.80 .

\title{
Data collection and data analysis process
}

After teaching "Electricity in Our Lives", researchers presented the required information about the concept maps and structured grid to the students. After this process, concept map activities and structured grid given to the students and was asked to fill. Finally the achievement test which is prepared by Ceylan (2008), given to students and was asked to answer. After that, answer sheets of the students who participate all activities were analyzed.

For the scoring achievement test, researchers gave same points to each item and scoring was done on 100 points. The scoring processes of the concept maps were made according to Novak and Gowin (1984)'s criteria. One point is given to examples and links, five points are given to hierarchies and ten points are given to cross-links. Then, calculated points proportioned and scored over 100. After that, researchers do the analysis on the statistic software. The scoring process of structured grid were made according to Johnstone, Bahar, \& Hansell (2000)'s criteria. According to this method, the following formula is used for scoring:

\author{
Point: $\frac{\mathrm{C} 1}{\mathrm{C} 2}-\frac{\mathrm{C} 3}{\mathrm{C} 4}$ \\ $\mathrm{C} 1$ : The number of correct boxes selected \\ $\mathrm{C} 2$ : The total number of correct boxes \\ C3: The number of wrong boxes selected \\ C4: The total number of wrong boxes
}

After the formula used, 1 is added to the points after that, the points multiplied by 5 (Johnstone, Bahar, \& Hansell, 2000). Then, the scores obtained by this formula proportioned and scored over 100. After that, researchers do the analysis on the statistic software. Spearman's rho test, Mann Whitney U test and descriptive analysis was applied and the results was assessed at $\mathrm{p}=0.05$ significance level. 


\section{Findings}

In the study, Spearman's rho test was conducted to find an answer to the first research question, "Is there a significant correlation between students' concept map points, students' structured grid points and students' achievement test points?" The results of Spearman's rho test are presented in Table 1.

Table 1 . The correlation analysis of concept map, structured grid and multiple choice test

\begin{tabular}{lccccc} 
& & $\begin{array}{c}\text { Achieveme } \\
\text { nt Test }\end{array}$ & $\begin{array}{c}\text { Structured } \\
\text { Grid }\end{array}$ & $\begin{array}{c}\text { Creating } \\
\text { Concept Map }\end{array}$ & $\begin{array}{c}\text { Filling Concept } \\
\text { Map }\end{array}$ \\
\hline Achievement Test & $\mathrm{r}$ & 1.000 & 0.323 & 0.512 & 0.806 \\
& $\mathrm{p}$ & & 0.132 & 0.013 & 0.000 \\
& $\mathrm{~N}$ & 23 & 23 & 23 & 23 \\
Structured Grid & $\mathrm{r}$ & 0.323 & 1.000 & 0.271 & 0.224 \\
& $\mathrm{p}$ & 0.132 & & 0.211 & 0.305 \\
Creating Concept & $\mathrm{N}$ & 23 & 23 & 23 & 23 \\
Map & $\mathrm{r}$ & 0.512 & 0.271 & 1.000 & 0.456 \\
& $\mathrm{p}$ & 0.013 & 0.211 & & 0.029 \\
Filling Concept Map & $\mathrm{N}$ & 23 & 23 & 23 & 23 \\
& $\mathrm{r}$ & 0.806 & 0.224 & 0.456 & 1.000 \\
& $\mathrm{p}$ & 0.000 & 0.305 & 0.029 & \\
& $\mathrm{~N}$ & 23 & 23 & 23 & 23 \\
\hline
\end{tabular}

There is a high significantly positive relationship between achievement test points and concept map filling activity points $(\mathrm{p}<0.05)$. There is also moderate significant positive relationship between achievement test points and concept map creating activity points $(p<0.05)$. However, the relationship between achievement test points and structured grid points were not statistically significant $(p>0.05)$. The relationship between structured grid points and concept map activities was also not statistically significant ( $p>0.05)$.

In the study, descriptive analysis was conducted to find an answer to the second research question which is 'How is changing the students' achievement test points, students' concept map activity points and students' structured grid points?". The results are presented in Table 2.

Table 2. Descriptive analysis of achievement test points, structured grid points and concept map activities' points

\begin{tabular}{lccccc}
\hline & $\mathrm{N}$ & $\bar{X}$ & $\mathrm{SD}$ & $\mathrm{Min}$ & $\mathrm{Max}$ \\
\hline Achievement Test & 23 & 61.21 & 16.42 & 28.00 & 84.00 \\
Structured Grid & 23 & 55.26 & 8.74 & 36.60 & 74.60 \\
Creating Concept Map & 23 & 16.24 & 15.25 & 0.00 & 50.00 \\
Filling Concept Map & 23 & 36.06 & 23.74 & 0.00 & 76.47 \\
\hline
\end{tabular}

After the descriptive analysis, the mean of the students' achievement test points was 61.21 over 100. Standard deviation of achievement test was calculated as 16.42. Students' lower score was found as 28 and students' higher score was found as 84 from the achievement test. The mean of the students' structured grid points was found as 55.26. Standard deviation of structured grid was calculated as 8.74. Students' lower score was found as 36.60 over 100 and students' higher score was found as 74.60 over 100 from the structured grid. The mean of the students' concept map creating activity points was found as 16.24. The mean of the students' concept map filling activity points was found as 36.06. Standard deviation of concept map filling activity is calculated as 23.47. In some answer sheets, there are none regarded correct or reasonable answers. For that reason the lower score of the concept map activities is found as 0 . The highest score of participating students in concept map filling activity was calculated 
as 76.47 over 100 .

In the study, Mann Whitney $U$ test was conducted to find an answer to the last research question which is "Is there a significant difference between students' concept map activity points and students' structured grid activity points based on gender?" The results are presented in Table 3.

Table 3. The results of Mann Witney U Test

\begin{tabular}{llccccc}
\hline & & $\mathrm{n}$ & Mean Rank & $\begin{array}{c}\text { Sum of } \\
\text { Ranks }\end{array}$ & $\mathrm{U}$ & $\mathrm{p}$ \\
Achievement & Woman & 13 & 13.58 & 176.50 & 44.500 & 0.202 \\
Test & Man & 10 & 9.95 & 99.50 & & \\
Structured Grid & Woman & 13 & 12.62 & 164.00 & 57.000 & 0.620 \\
& Man & 10 & 11.20 & 112.00 & & \\
Creating & Woman & 13 & 12.00 & 156.00 & 65.000 & 1.000 \\
Concept Map & Man & 10 & 12.00 & 120.00 & & \\
Filling Concept & Woman & 13 & 13.08 & 170.00 & 51.000 & 0.383 \\
Map & Man & 10 & 10.60 & 106.00 & & \\
\hline
\end{tabular}

There was no significant difference between men's achievement test points (Mean Rank=9.95) and women's achievement test points (Mean Rank= 13.58) based on gender ( $>0.05)$. There was no significant difference between men's structured grid points (Mean Rank=11.20) and women's structured grid points (Mean Rank=12.62) based on gender $(\mathrm{p}>0.05)$. There was no significant difference between men's concept map creating activity points (Mean Rank=12.00) and women's concept map creating activity points (Mean Rank=12.00) based on gender ( $>0.05)$. There was no significant difference between men's concept map filling activity points (Mean Rank=10.60) and women's concept map filling activity points (Mean Rank=13.08) based on gender $(\mathrm{p}>0.05)$.

Table 4. The means of women's and men's points for all activities

\begin{tabular}{llll}
\hline & & $\mathrm{n}$ & Mean \\
Achievement & Woman & 13 & 64.92 \\
Test & Man & 10 & 56.40 \\
Structured Grid & Woman & 13 & 56.01 \\
& Man & 10 & 54.30 \\
Creating & Woman & 13 & 15.83 \\
Concept Map & Man & 10 & 16.76 \\
Filling Concept & Woman & 13 & 39.36 \\
Map & Man & 10 & 31.76 \\
\hline
\end{tabular}

For all activities, women's and men's points' arithmetic means is almost the same. For achievement test; women's arithmetic means calculated as 64.92, men's arithmetic means calculated as 56.40, for structured grid; women's arithmetic means calculated as 56.01, men's arithmetic means calculated as 54.30, for concept map creating activity; women's arithmetic means calculated as 15.83, men's arithmetic means calculated as 16.76, for concept map filling activity; women's arithmetic means calculated as 39.36, men's arithmetic means calculated as 31.76 . 


\section{Discussion and Conclusion}

As the result of analysis, there was found moderate and positive significant relationship between students' achievement test points and students' creating concept map activity points. After the analysis there was also found high and positive significant relationship between students' achievement test points and students' concept map filling activity points. From these results it can be said that, two concept map activities also can measure the same skills like achievement test. For that reason it can be expressed that, concept map activities served their purpose. There are some studies with similar and different results in the literature. In a study conducted by Eroğlu and Kelecioğlu (2011), concept map results and short answer test results were compared and moderate, significant positive relationship was found. Kandil İngeç (2008) found a poor and significant relationship between achievement test and concept map points in his study. There is few correlation studies have been found related to the structured grid while performing the literature review. In a study, Hassan, Hill and Reid (2004) compared a structured grid results with a end of term exam results and they found significant relationships ranging between 0.19 and 0.34 . In another study, Danili and Reid (2005) found a poor, significant positive relationship between multiple-choice test results and structured grid results.

In this study, researchers investigated the correlation between structured grid points and achievement test points. As a result of this study, there was no statistically significant relationship between structured grid points and achievement test points. Students' being not so familiar with structured grid activities can be seen as a cause of this situation. In the literature it is stated that, teachers' level of use of the alternative assessment and evaluation tools less than the level of use of the traditional measurement tools (Adanalı \& Doğanay, 2010; Akbaş \& Gençtürk, 2013; Çalışkan \& Kaş1kç1, 2010). In addition to it is mentioned that, teachers' level of knowledge is not enough about alternative evaluation techniques (Sağlam-Arslan et all., 2008; Şenel Çoruhlu et all., 2009; Çalışkan \& Kaşıkçı, 2010; Güneş, et all., 2010). Because of teachers abstaining from to use structured grids, students' lack of experience about that can be taken naturally.

According to the results of descriptive analysis, students' highest arithmetic mean came from achievement test. Mean of students' structured grid points almost same to mean of students' achievement test points. Apart from that, arithmetic mean of students' concept map filling activity points was found higher than arithmetic mean of students' concept map creating activity. Students' being familiar with multiple-choice tests are thought as the reason of this situation. As another result, arithmetic mean of students' concept map filling activity points found higher than arithmetic mean of students' concept map creating activity points. This situation can be interpreted as links between concepts could not form accurately by students. Kandil İngeç (2008) stated that, prospective teachers know the concepts but they couldn't create the links between concepts completely.

In the results of Man Whitney U test, there aren't any significant differences between achievement test points, concept map activities points and structured grid points according to gender. This result can be interpreted, as not having any effects on these activities points' by gender. Saracaloğlu, Serin and Bozkurt (2001) said that, there wasn't any significant difference on overall success of students by gender.

Last of all, researchers found that, students were more successful on achievement tests. It is seen as a reason of this result that, students have familiar with multiple-choice tests and also 
students have not very familiar with alternative assessment and evaluation tools. Students were statistically more successful at concept map filling activity in concept map activities. This situation can mean that, students couldn't create the links between concepts in fully. At the end of the analysis the results showed that, there was no gender impact to the points.

\section{Recommendations}

The following recommendations are presented according to the study results.

(1) Alternative assessment and evaluation methods can be use in addition to traditional methods. This situation can be lead to students get accustomed to different evaluation techniques.

(2) Teachers can be informed about alternative assessment and evaluation techniques and with this way teachers can more use the alternative assessment and evaluation methods in their classes.

\section{References}

Adanalı, A., Doğanay, K. (2010). Beşinci sınıf sosyal bilgiler öğretiminin alternatif ölçme değerlendirme etkinlikleri açısından değerlendirilmesi [The evaluation of alternative assessment practices in fifth grade social studies instruction]. Çukuorva Üniversitesi, Sosyal Bilimler Enstitüsü Dergisi, 19(1), 271-292.

Akbaş, Y., Gençtürk, E. (2013). Coğrafya öğretmenlerinin alternatif ölçme-değerlendirme teknikleri ile ilgili görüşleri: Kullanma düzeyleri, sorunlar ve sınırlılıklar [Geography teachers' views about alternative assessment and evaluation techniques: usage levels, problems and lımitations]. Doğu Coğrafya Dergisi, 30(18), 331-355.

Altınok, H., Ün Açıkgöz, K. (2006). İşbirlikli ve bireysel kavram haritalamanın fen bilgisi dersine yönelik tutum üzerindeki etkileri [Effects of cooperative and individual concept mapping on attitudes toward science]. Hacettepe Üniversitesi Ĕ̈itim Fakültesi Dergisi, 30, 21-29.

Bahar, M., Nartgün, Z., Durmuş, S., Bıçak, B. (2006). Geleneksel ve alternatif ölçme ve değerlendirme ögretmen el kitabl [Traditional and alternative assessment and evaluation of teachers' manual]. Ankara: PegemA.

Batdı, V. (2014). Kavram haritası tekniği ile geleneksel öğrenme yönteminin kullanılmasının öğrencilerin başarıları, bilgilerinin kalıcılığı ve tutumlarına etkisi: Bir meta-analiz çalışması [The effect of using the concept-mapping technique and traditional methods on the achievement, retention and attitudes of students: a meta-analytic study]. Dumlupınar Üniversitesi Sosyal Bilimler Dergisi, 42, 93-102.

Büyüktokatlı, N., Bayraktar, Ş. (2014). Fen eğitiminde alternatif ölçme değerlendirme uygulamaları [Alternative assessment practices in science]. Pegem Ĕ̈itim ve Ögrretim Dergisi, 4(1), 103-126.

Ceylan, H. (2008). İlkögrretim fen ve teknoloji dersinde altıncı sınıf ögrencilerine elektrik konusunun ögretiminde kavramsal değişim yaklaşımının öğrenci başarısına ve tutumuna etkisi [The effect of conceptual change approach on teaching the subject of electricity to sixth grade students in primary education sclence and technology course]. Yüksek Lisans Tezi, Gazi Üniversitesi, Eğitim Bilimleri Enstitüsü, Ankara.

Çalışkan, H., Kaşıkçı, Y. (2010). The application of traditional and alternative assesment and evaluation tools by teachers in social studies. Procedia Social and Behavioral Sciences, 2, 4152-4156. 
Çepni, S. (2010). Araştırma ve proje çalışmalarına giriş [Introduction to research and project work]. (5. Bask1) Trabzon.

Çıldır, I., Şen, A. İ. (2006). Lise öğrencilerinin elektrik akımı konusundaki kavram yanılgılarının kavram haritalarıyla belirlenmesi [Identification of high school students' misconception about electric current by concept maps]. Hacettepe Üniversitesi Ĕ̈itim Fakültesi Dergisi, 30, 92-101.

Danili, E., \& Reid, N. (2005). Assessment formats: do they make a difference?. Chemistry Education Research and Practice, 6(4), 204-212.

Duban, N. \& Küçükyılmaz, E. A. (2008). Sınıf öğretmeni adaylarının alternatif ölçmedeğerlendirme yöntem ve tekniklerinin uygulama okullarında kullanımına ilişkin görüşleri [Primary education pre-service teachers' opinions regarding to the use of alternative measurement-evaluation methods and techniques in practice schools]. Illkögretim Online, 7(3), 769-784.

Durmus, S., \& Karakirik, E. (2005). A computer assessment tool for structural communication grid. Online Submission, 4(4).

Eroğlu, M. G., \& Kelecioğlu, H. (2011). An analysis on the validity and reliability of concept map and structural communication grid scores. Hacettepe Üniversitesi Ĕ̈itim Fakültesi Dergisi, 40, 210-220.

Gedizgil, Z., \& Deryakulu, D. (2008). Kavram haritalamanın bilgisayardan hoşlanma ve bilgisayar dersine yönelik güdülenme üzerindeki etkisi [The effects of concept mapping on computer liking and motivation to computer course]. Hacettepe Üniversitesi Ĕ̈itim Fakültesi Dergisi, 34, 106-115.

Güleç, S., \& Alkış, S. (2003). İlköğretim birinci kademe öğrencilerinin derslerdeki başarı düzeylerinin birbiri ile ilişkisi [The relationships of primary school students' success levels in lessons with each other]. Illkögretim Online, 2(2), 19-27.

Güneş, T., Dilek, N. Ş., Hoplan, M., Çelikoğlu, M., \& Demir, E. S. (2010, Kasım). Öğretmenlerin alternatif değerlendirme konusundaki görüşleri ve yaptıkları uygulamalar [Teachers' opinions on alternative assessment and their applications]. In International Conference on New Trends in Education and Their Implications, Antalya.

Hassan, A. K., Hill, R. A., \& Reid, N. (2004). Ideas underpinning success in an introductory course in organic chemistry. University Chemistry Education, 8(2), 40-51.

Johnstone, A. H., Bahar, M., \& Hansell, M. H. (2000). Structural communication grids: A valuable assessment and diagnostic tool for science teachers. Journal of Biological Education, 34(2), 87-89.

Kandil İngeç, Ş. (2008). Kavram haritalarının değerlendirme aracı olarak fizik eğitiminde kullanılmas1 [Using concept maps as an assestment tool in physics education]. Hacettepe Üniversitesi Ĕgitim Fakültesi Dergisi, 35, 195-206.

Kaptan, F. (1998). Fen öğretiminde kavram haritası yönteminin kullanılması [The using of concept map methods in science teaching]. Hacettepe Üniversitesi Ĕ̈itim Fakültesi Dergisi, 14, 95-99.

Karakuş, U. \& Öztürk Demirbaş, Ç. (2011). Coğrafya öğretmenlerinin ölçme ve değerlendirme araçlarını kullanımı (Kırşehir Örneği) [The usage of the assessment tools by geography teachers (Sample of Kırşehir)]. Milli Eğitim Dergisi, 189, 71-81.

Karamustafaoğlu, S., Çağlak, A., \& Meşeci B. (2012). Alternatif ölçme değerlendirme araçlarına ilişkin sınıf öğretmenlerinin öz yeterlilikleri [Self-efficiency of primary school teachers related to the alternative testing and assessment tools]. Amasya Üniversitesi Eğitim Fakültesi Dergisi, 1(2), 167-179.

Kaya, A., Balay, R. \& Göçen, A. (2012). Öğretmenlerin alternatif ölçme ve değerlendirme tekniklerine ilişkin bilme, uygulama ve eğitim ihtiyacı düzeyleri [The level of 
teachers' knowing, application and training need on alternative assessment and evaluation techniques]. International Journal of Human Sciences, 9(2), 1303-5134.

Korkmaz, H. \& Kaptan, F. (2002). Fen eğitiminde öğrencilerin gelişimini değerlendirmek için portfolyo kullanımı üzerine bir inceleme [An investigation on using portfolio for assessing students' development in science education]. Hacettepe Ĕgitim Fakültesi Dergisi, 23, 167-176.

Korkmaz, H. \& Kaptan, F. (2005). Fen eğitiminde öğrencilerin gelişimini değerlendirmek için elektronik portfolyo kullanımı üzerine bir inceleme. The Turkish Online Journal of Educational Technology, 4(1), 101-106.

Kuran, K. \& Kanatlı, F. (2009). Alternatif ölçme değerlendirme teknikleri konusunda sınıf öğretmenlerinin görüşlerinin değerlendirilmesi [The evaluation of classroom teachers' opinions on the alternative assessment techniques]. Mustafa Kemal Üniversitesi Sosyal Bilimler Enstitüsü Dergisi, 6(12). 209-234.

Novak, J. D., \& Gowin, D. B. (1984). Learning how to learn. Cambridge University Press.

Ogan Bekiroğlu, F. (2004). Ne kadar başarıll? Klasik ve alternatif ölçme-değerlendirme yöntemleri ve fizikte uygulamalar [How successful? Classical and alternative assessment methods and their applications in physics]. Ankara: Nobel.

Okur, M. \& Azar, A. (2011). Fen ve teknoloji dersinde kullanılan alternatif ölçme ve değerlendirme tekniklerine ilişkin öğretmen görüşleri [Primary teachers' opinions about alternative measurement and assessment techniques used in science and technology course]. Kastamonu Ë̆itim Dergisi, 19(2), 387-400.

Özdemir, A. Ş. (2005). Analyzing concept maps as an assesstment (evaluation) tool in teaching mathematics. Journal of Social Sciences, 1(3), 141-149.

Özdemir, S. M. (2010). İlköğretim öğretmenlerinin alternatif ölçme ve değerlendirme araçlarına ilişkin yeterlilikleri ve hizmetiçi eğitim ihtiyaçları [Elementary teacher competencies and inservice training needs in alternative measurement and assessment tools]. Türk Ĕgitim Bilimleri Dergisi, 8(4), 787-816.

Özsevgeç, T. \& Karamustafaoğlu, S. (2010). Öğretmen adaylarının geleneksel ve yapılandırmacı ölçme-değerlendirme yaklaşımlarına yönelik profilleri [Pre-service student teachers' profiles of the measurement-assessment approaches]. Türk Eğitim Bilimleri Dergisi, 8(2), 333-354.

Öztürk, N., Yalvaç Hastürk, H. G. \& Demir, R. (2013). İlköğretim 4-5. sınıf fen ve teknoloji dersi öğretim programlarındaki ölçme ve değerlendirme yöntemlerine ilişkin öğretmen görüşleri [Teachers' opinions about the assessment and evaluation methods employed in elementary $4-5^{\text {th }}$ grades school science and technology teaching programs]. Dicle Üniversitesi Ziya Gökalp Ë̆itim Fakültesi Dergisi, 20, 25-36.

Sağlam-Arslan, A., Avcı, N. \& İyibil, Ü. (2008). Fizik öğretmen adaylarının alternatif ölçmedeğerlendirme yöntemlerini algilama düzeyleri [Physics prospective teachers' perception levels concerning alternative evaluations methods]. Dicle Üniversitesi Ziya Gökalp Ĕ̈itim Fakültesi Dergisi, 11, 115-128.

Saracaloğlu, A. S., Serin, O. \& Bozkurt, N. (2001). Dokuz Eylül Üniversitesi eğitim bilimleri enstitüsü öğrencilerinin problem çözme becerileri ile başarıları arasındaki ilişki [The relationship between the problem solving skills and the achievement of graduate students of the graduate school of educational science]. Marmara Üniversitesi Atatürk Ĕ̈itim Fakültesi Ĕgitim Bilimleri Dergisi, 14, 121-134.

Şaşmaz Ören, F., Ormancı, Ü. \& Evrekli, E. (2011). Fen ve teknoloji öğretmen adaylarının alternatif ölçme-değerlendirme yaklaşımlarına yönelik öz-yeterlilik düzeyleri ve görüşleri [The science and technology pre-service teachers' self-efficacy levels and opinions about alternative assessment and evaluation approaches]. Kuram ve Uygulamada Eğitim Bilimleri, 11(3), 1675-1698. 
Şenel Çoruhlu, T., Er Nas, S. \& Çepni, S. (2009). Fen ve teknoloji öğretmenlerinin alternatif ölçme-değerlendirme tekniklerini kullanmada karşılaştıkları problemler: Trabzon örneği [Problems facing science and technology teachers using alternative assessment technics: Trabzon sample]. Yüzüncü Yll Üniversitesi Eğitim Fakültesi Dergisi, 1(6), 122-141.

Tan, Ş. (2008). Öğretimde ölçme ve değerlendirme kpss el kitabı [Measurement and evaluation in education KPSS manual](2. Bask1). Ankara: Pegem Akademi.

Usta, S., Çığır Dikyol, D. \& İnce, E. (2010). The alternative evaluation tools choosen by social and science teacher candidates. Procedia Social and Behavioral Sciences, 2, 3457-3462.

Yeşilyurt, E. (2012). Fen ve teknoloji dersinde kullanılan ölçme-değerlendirme yöntemleri ve karşılaşılan güçlükler. [Measurement and assessment methods used at science and technology lesson and the difficulties encountered]. Electronic Turkish Studies, 7(2), 1183-1205.

Yıldız İ. \& Uyanık N. (2004). Matematik eğitiminde ölçme değerlendirme üzerine [On measurement and evaluation in mathematics teaching]. Gazi Üniversitesi Kastamonu Ĕ̈itim Dergisi, 12(1), 97-104. 